\title{
膝関節部骨折と膝関節可動域影響因子
}

\author{
九州労災病院整形外科 \\ 久我哲也・井原秀 俊
}

\section{Factors Affected the Range of Motion of the Knee after Fractures Including the Knee}

by

Tetsuya Kuga and Hidetoshi Ihara

Department of Orthopaedic Surgery, Kyushu Rosai Hospital

\begin{abstract}
To examine important factors in the range of motion of the knee after fractures including the knee: supracondylar and condylar fractures of the femur and tibial condylar fractures, ranges of motion finally obtained after operations in 77 cases were investigated. Five factors which seemed to affect the range of motion were selected and analized statistically : the site of the fracture, the period of post-operative immobilization, the method of internal fixation, the period between injury and operation, and the age of patients. Analysis by Quantification 1 showed that the most important factor affecting the final range of motion was the site of fracture, and the period of post-operative immobilization followed. It appears that in the femur intra- and extra-articular tissues are easier to adhesion. So to avoid the contracture after operation, motion exercise should be started as early as possible if the fracture was well fixed.
\end{abstract}

\section{はじめに}

膝関節部骨折は，膝関節拘縮が起こりやすい骨折で ある。それは, 骨折治瘾機転における関節内結合組織 の増生，骨折時扔よび手術時に合併する軟部組織損傷 とその瘢痕組織の増生, その結果生ずる近接する膝伸 展機構の滑走阻害, などの理由による。 そこで膝関節 拘縮を最小限に抑えるためには，とくにどのような点 に留意すべきかを明らかにするため, 大腿骨遠位端お よび脛骨近位端の膝関節部骨折について, 術後獲得さ れた可動域とそれに影響を及ほす諸因子について検討 した。

\section{対象と方法}

昭和 58 年から昭和 62 年までの 5 年間に当院におい て観血的治療を行った膝関節部骨折 77 例を対象とし た。その内訳は大腿骨顆上骨折 6 例, 大腿骨顆部骨折 19 例, 脛骨顆部骨折 52 例である. 関節部骨折とは骨折
線が関節包内にある関節内骨折, 骨折線が関節包内外 にわたる関節骨折, 骨幹端部骨折である関節周辺骨折 の総称であるが ${ }^{11}$,ここでは膝蓋骨骨折および骨軟骨骨 折, 靶帯性剝離骨折は除外した。部位は大腿骨側では 内顆 5 例, 外顆 8 例, 両顆 6 例, 脛骨側では内顆 3 例, 外顆 33 例, 両顆 16 例であった。性別では男性 50 例, 女性 27 例. 年令は $16 \sim 85$ 才 (平均 45 才). 右膝 37 例, 左膝 40 例であった。受傷原因は交通事故によるものが 49 例と多く, なかでもバイク・自転車によるものが 32 例と大部分を占めた。ついで転倒 8 例, 転落 8 例, ス ポーツ 6 例などであった。合併損傷は脛骨顆部骨折 52 例のうち外側半月板損傷 20 例, 腓骨頭骨折 13 例であ り，内側側副勒帯損傷はストレス撮影などで確認され たのは 2 例で, 観血的に治療された症例はなかった。 開放性骨折は 9 例で大腿骨顆部骨折に 7 例, 脛骨顆部 骨折に 2 例と大腿骨側に多く見られた。治療法は大腿 骨顆上骨折 6 例はプレートによる内固定, 大腿骨顆部 骨折のうち単顆骨折 13 例はスクリューによる内固定, 
両顆骨折 6 例では 4 例にプレート，2 例にスクリュー による内固定が行われた。脛骨顆部骨折のうち単顆骨 折 36 例では 17 例にスクリュー, 11 例にプレートによ る内固定, 両顆骨折 16 例はプレートによる内固定が行 われた. 脛骨顆部骨折 52 例のうち 35 例に骨移植が行 われた。

これらの症例について, 術後最終的に獲得された可 動域を調査した。最終可動域に達する平均日数は, 大 腿骨側で $177 \pm 86$ 日, 脛骨側で $157 \pm 113$ 日であり, 両 者間に有意差はなかった。可動域に影響をおよぼす因 子として, 骨折部位, 合併損傷, 内固定の種類, 術後 整復状態, 年令, 受傷から手術までの期間, 術後固定 期間，の 7 因子を選んだ。これら 7 因子と可動域との 関係を, 平均值の検定または単回帰分析にて, 検討し た。次に膝関節部骨折として脛骨側, 大腿骨側に共通 な因子である骨折部位, 内固定の種類, 年令, 受傷か ら手術までの期間, 術後固定期間の 5 因子については, 数量化理論 I 類を用いて分析した ${ }^{17)}$.

\section{結果}

7 因子についての平均値の検定または単回帰分析に よる, 可動域との関係は次のとおりであった.（1）骨折 部位: 脛骨側 $133 \pm 23^{\circ}$, 大腿骨側 $100 \pm 41^{\circ}$ であり, 脛 骨より大腿骨側に不良例が多かった，大腿骨では顆部
$109 \pm 40^{\circ}$, 顆上 $70 \pm 34^{\circ}$ と頸部より顆上骨折に不良例が 多かった. 脛骨では単顆と両顆に有意差はなかった. (2) 合併損傷 : 脛骨顆部骨折については外側半月板損 傷の有無による有意差はなかったが, 腓骨頭骨折を伴 うものは $124 \pm 22^{\circ}$, 伴わないものは $137 \pm 21^{\circ}$ と腓骨頭 骨折を伴うものは不良であった，大腿骨については開 放性，閉鎖性の有意差はなかった.（3）内固定の種類： 脛骨側ではプレート $124 \pm 17^{\circ}$ ，スクリュー $140 \pm 17^{\circ}$, 大腿骨側ではプレート $70 \pm 36^{\circ}$, スクリュー $114 \pm 34^{\circ}$ で あり脛骨および大腿骨とも，スクリューのみで固定で きたものは成績が良かった. (4)術後整復状態: 脛骨顆 部骨折では術後整復状態が良（転位なし）の症例は $141 \pm 18^{\circ}$, 不可(転位 $5 \mathrm{~mm}$ 以上)の症例は $109 \pm 35^{\circ}$ と 良と不可の間に有意差を認めた. (5) 年令：脛骨顆部骨 折では年令が高いほど可動域が減少する負の相関（相 関係数-0.437）を認めた.（6)受傷から手術までの期 間：相関は認められなかった. (7)術後固定期間：脛骨 側では相関係数 -0.351 , 大腿骨側では相関係数一 0.523 と脛骨, 大腿骨とも固定期間が長いほど可動域が 減少する負の相関を認めた。

合併損傷と術後整復状態を除く 5 因子については数 量化理論 I 類による解析を行った(図 1 ). 術後最終的 に獲得された可動域を目的変数とし, それぞれの因子 をいくつかのカテゴリーに分けた.これら 17 のカテゴ

表 1 数量化理論 I 類による解析

\begin{tabular}{|c|c|c|c|c|c|c|c|}
\hline 因 & 子 & 項 目 & & カテゴリー分 類 & 症 & 偏 相 関 係 数 & 標準偏回㷌係数 \\
\hline 部 & & & 位 & $\begin{array}{lll}\text { 脛 } & & \text { 骨 } \\
\text { 大 } & \text { 腿 } & \text { 骨 }\end{array}$ & $\begin{array}{l}46 \\
25\end{array}$ & 0.450 & $\begin{array}{r}9.026 \\
-16.608\end{array}$ \\
\hline 年 & & & 令 & $\begin{array}{lll}29 & \text { 才 } & \text { 以 } \\
30 & \sim 44 & \text { 才 } \\
45 & \sim 59 & \text { 才 } \\
60 & \text { 才 } & \text { 上 }\end{array}$ & $\begin{array}{l}18 \\
18 \\
16 \\
19\end{array}$ & 0.280 & $\begin{array}{r}3.602 \\
7.484 \\
0.872 \\
-11.238\end{array}$ \\
\hline 受傷か & ら手術 & 行までの期 & 嫺 & $\begin{array}{cccc}4 & \text { 日 } & \text { 以 } & \text { 下 } \\
5 & \sim & 9 & \text { 日 } \\
10 & \sim & 14 & \text { 日 } \\
15 & \text { 日 } & \text { 上 }\end{array}$ & $\begin{array}{l}17 \\
29 \\
13 \\
12\end{array}$ & 0.328 & $\begin{array}{r}0.864 \\
3.859 \\
5.943 \\
-16.988\end{array}$ \\
\hline 内 固 & 定 & の 種 & 類 & 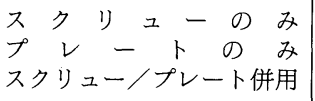 & $\begin{array}{l}35 \\
25 \\
11\end{array}$ & 0.415 & $\begin{array}{r}10.070 \\
-\quad 6.555 \\
-17.143\end{array}$ \\
\hline 術 後 & 固 & 定 期 & 間 & $\begin{array}{llll}19 & \text { 日 } & \text { 以 } & \text { 下 } \\
20 & \sim 29 & \text { 日 } \\
30 & \sim & 39 & \text { 日 } \\
40 & \text { 日 } & \text { 以 } & \text { 上 }\end{array}$ & $\begin{array}{l}15 \\
22 \\
15 \\
19\end{array}$ & 0.417 & $\begin{array}{r}13.478 \\
8.128 \\
-13.139 \\
-\quad 9.680\end{array}$ \\
\hline
\end{tabular}

5 因子：重相関係数 0.752 , 寄 与 率 0.566 
リーを説明変量とし，可動域の予測式を算出した．こ の予測值が観測值をどの程度よく予測しているかを表 す重相関係数は 0.752 , 寄与率は 0.566 であり, 可動域 の変動のうち約 $57 \%$ \%これら 5 つの因子で説明される ことを示している.この数值はやや低いものの，今回 対象とした骨折の範囲が広く, 大腿骨側, 脛骨側に共 通する因子として転位度, 合併損傷, 術後整復状態な ど臨床的に重要な因子を選択することができなかった ためやむを得ないものと思われた，各因子がどの程度 可動域に関与するかの指標である偏相関係数をみると, 大きく影響をおよぼす因子は骨折部位であり，ついで 術後固定期間，固定方法，受傷から手術までの期間， 年令の順であった。

\section{考察}

膝関節拘縮をきたす原因として大腿骨および膝関節 部骨折の占める割合は大きい。諸家の報告によれば膝 授動術が必要となった症例の多くが大腿骨および膝関 節部骨折である(4) 2918 . われわれの症例でも脛骨顆部 骨折 52 例のうち 12 例, 大腿骨顆部および顆上骨折 27 例のうち 9 例に対して徒手的授動術や鏡視下授動術が 行われており，また大腿骨顆上骨折 6 例のうち 2 例に は観血的授動術が行われている.

その易拘縮性の原因として組織別に次の要因が考え られる ${ }^{11}$.1）骨性要因：骨折部の治凂機序による結合 組織増生，骨過形成，易療着性，2) 軟部組織性要因: 外傷および手術操作による皮下・筋組織などの損傷と, それに伴う結合組織増生と易癠着性（とくに，膄蓋上 位での大腿四頭筋の癒着は, 伸展機構の短縮をもたら す)，3）関節性要因：関節軟骨の壊死，滑膜 - 脂肪体 の弾性低下と疫痕化, 関節内結合組織架橋形成による 膝滑り転がり運動の阻害, 4) 神経性要因: 関節周辺の 固有受容器の機能障害に基づく, 膝安定性と防御反応 の低下による膝運動能力の劣化, などである。これら の膝関節部骨折に特有な諸要因に, 年令, 術後一定期 間の外固定などの因子が加わり,さらに痖着が助長さ れることになる。

今回の検討で，可動域にもっとも影響を及ぽす因子 は骨折部位であったが, 易拘縮性の要因から考えると, 大腿骨側は滕蓋大腿関節を含み伸展機構の瘾着など骨 性および軟部組織性要因の程度が大きいためと考えら れる. 次いで可動域に影響を及ぼす因子は術後固定期 間であった．固定により関節性および神経性要因の関
与が大きくなると考えられる，関節固定による関節内 の影響（弊害）として，1）関節腔の閉鎖に至るまでの 線維脂肪滑膜性結合組織の時間依存性増殖 $\left.{ }^{1213) 161}, 2\right)$ 接触面での持続性圧迫による軟骨壊死 ${ }^{12144)}$ ，3）間葉性 骨髄組織による軟骨下骨層の破断 ${ }^{233)}$ ，4) 非接触面での 軟骨びらんと潰崵形成 ${ }^{3)}$ ，5）癒着付着部での関節軟骨 亀裂同士の癒着 ${ }^{2335)}$ ，などが挙げられている.

したがって, 術後のギプス固定などは最小限にする ことが必要であり, それが, もっとも整形外科医の手 腕が問われるところでもある．そのためには，骨折部 の強固な固定も重要であるが, それよりも, ある程度 の固定性が得られれば，できるだけ早期に膝関節運動 を開始するべきであると考える，骨折を第一義に考え るか, 関節を第一義に考えるかという認識の問題から， 骨接ぎ医を越えて関節外科医へと視点を移すべきであ る。それには, 最近普及し始めた CPM (continuous Passive Motion)を利用するのもいいであろう.しかし， 目指すは単なる滕可動域訓練から, 膝周囲筋・固有受 容器を含めた膝運動訓練であり, これらを早期に開始 することにより機能的膝運動性の獲得が期待できるで あろう。

\section{ま と め}

1. 当院において観血的治療を行った䐂関節部骨折 77 例について術後可動域を検討し, 主に数量化理論 I 類を用いて分析した。

2. その結果, 術後可動域に影響を及ほす因子とし て重要なものは骨折部位, 術後固定期間, 固定方法, 受傷から手術までの期間，年令の順であった。また， 部位では大腿骨側が膝蓋大腿関節を含み伸展機構の瘜 着の程度が大きいと考えられた。

3. 術後は, ある程度の固定性が得られれば, 可能 なかぎり早期に膝運動の諸訓練を行うことが機能的膝 運動性の獲得に重要であると考えた。

(資料の統計処理について御教示および御助力いただいた九 州労災病院リハビリテーション診療科 堤文生氏に深謝いた します.)

\section{参 考 文 献}

1）安藤徳彦: 関節拘縮の発生機序. 総合リ八, $5: 1005$ $-1012,1977$.

2) Enneking, W.F. et al.: The Intra-Articular Effects of Immobilization on the Human Knee. J. Bone and Joint Surg., 54-A : 973-985, 1972. 
3) Evans, E. B. et al. : Exmental immobilization and remobilization of rat knee joints. J. Bone and Joint Surg., 42-A : 737-758, 1960.

4）冨士川恭輔・他 : Infrapatellar Extensor Apparatus の Antero-proximal Advancementによる膝関節授動 術について. 臨床整形外科, $18 ： 19-28,1983$.

5) Hall, M. C. : Cartilage changes after exprimental immobilization of the knee joint of the young rat. J. Bone and Joint Surg., 45-A : 36-44, 1963.

6）片田江民雄・他：荥関節授動術の小経験。一膝関節周 辺骨折後の拘縮膝に対して一. 整形外科と災害外科, $33: 676-678,1985$.

7）桑波田恵生・他：膝関節拘縮に対する関節形成術. 一 適応, 手術法と成績一. 季刊関節外科, $1: 317-326,1982$.

8）水田博志・他：膝関節拘縮に対する镜視下授動術. 整 形外科と災害外科, $35: 1227-1230,1987$.

9）守家泰一郎・他：膝関節拘縮に対する Judet の関節授 動術の経験. 整形外科と災害外科, $36: 907-909,1988$.

10）榊田喜三郎・他：膝関節顆部骨折の治療成績. 整形外 科, $26: 1069-1077,1975$.

11）榊田喜三郎・他：関節部骨折その 1 : 南江堂. 東京, 1986.

12) Salter, R. B. et al.: The effects of continuous compression on living articular cartilage. J. Bone and Joint Surg., 42-A : 31-49, 1960.

13) Thaxter, T.H. et al.: Degeneration of immobil- ized knee joints in rats. J. Bone and Joints Surg., 47 -A : 567-585, 1965

14) Trias, A. : Effect of persistent pressure on the articular cartilage. J. Bone and Joint Surg., 43-B : 376-386, 1961.

15）帠井正明・他：膝関節顆部骨折の観血的治療経験．整 形外科と災害外科, $37: 809-811,1988$.

16）八百板沙：長期固定による膝関節拘縮の発生と修復 に関する実験的研究。日整会誌，40：431-453，1966.

17）山本 稔・他：下腿骨骨折の骨痖合時期推定. 一数量 化理論 I 類の応用一. 整形・災害外科, $28: 89-93,1985$.

18）弓削大四郎：膝関節硬着に対する. R. Judet の関節授 動術。季刊関節外科, $1: 327-334 ， 1982$.

質 問座長 岩㴊亮

大腿骨，脛骨をいっしょに論じるのは無理があるの ではないか？

解 答州労災病院 久我 哲也 それぞれの部位では拘縮の機序が異なり，共通な因 子の選択も困難であった．部位を限定した方が数量化 理論 I 類による予測式も観測值に近いものとなる. 